\section{Growth of Industrial Organisations}

In the second of the series of lectures on industrial affairs at the Imperial College of Science and Technology, Mr. Austin Hopkinson discussed the advantages of the small industrial organisation. In his submission, there is no evidence that increasing the size of an industrial concern leads normally to an increase in efficiency; indeed history shows that most very large organisations of this type have soon become unstable, and their collapse has led to the loss of immense amounts of capital. A distinction should be drawn, however, between natural and artificial expansion. A limit to natural expansion by internal growth or by absorption of less efficient competitors is set only by the managerial capacity of individuals, and the ideal size cannot be expressed therefore by any simple formula such as statisticians have attempted to devise. When for any reason, however, a concern is expanded artificially beyond this limit, the expedients resorted to in attempts to establish financial stability are likely to be contrary to the interests of the community as a whole. The fact that very large industrial organisations have exceptional power to influence politicians, trade union leaders and the Press, makes them a potential danger to democracy, and, although Great Britain is justly proud of the integrity of its political and industrial life, the possibilities of abuses in the region where they overlap are exceptional and cannot be disregarded.

\section{Defects of Large Industrial Units}

In Mr. Hopkinson's view, the dangerous influence of large industrial concerns is not offset by any contribution to the happiness and prosperity of the community. The existence of twenty separate firms engaged in a particular branch of industry means twenty sources of energy and enterprise: their amalgamation into one large unit eliminates nineteen of these sources. The only way in which a nation can preserve a standard of living higher than that of others is by continuing to produce goods of higher quality or goods which the others cannot produce at all : tariffs and embargoes are merely temporary expedients. It follows therefore that competition from countries with a lower standard of life can be met only by frequent changes in the nature, form or design of the goods produced; but it is just this condition which the large organisation finds most difficult to meet, owing to the inertia resulting from its very size. Again, very large firms have the power to stimulate markets by intensive advertising and hire-purchase schemes, but by thus compressing the purchasing power of a life-time into a few years, an unhealthy state of the market is induced, and a temporary advantage may be wiped out by a subsequent collapse. Finally, the estimate that 44 per cent of total factory production in Great Britain is in the hands of firms employing less than two hundred people indicates the important part which the small concerns play in industrial life: their contribution to the national exchequer is, no doubt, proportionately great.

$$
\text { No. 3291, Vol. 130] }
$$

\section{Typhoon Season in the Far East}

THE cyclone season of the northern tropics is this year being extended abnormally far into the autumn in the Far East as well as in the West Indies, for a typhoon visited the Loo-Choo Islands so late as November 14, and reached Tokyo late on the following night. The wind is reported to have blown with a speed of nearly a hundred miles an hour, and to have caused much material damage. The loss of life was fortunately small compared with that caused by the Cuban storm five days earlier. Although there seems to be no essential difference between the typhoon of the western part of the North Pacific and the West Indian hurricane, both being typical examples of the tropical cyclone, the typhoon season is not concentrated into a few summer and early autumn months to nearly the same extent as happens with the West Indian storms. There is, however, more similarity in the seasonal distribution of those storms that reach Japan. July, August and September are the dangerous months for Japan and the neighbouring seas; whereas the seas farther to the south are occasionally affected by a typhoon even in mid-winter and early spring, the occurrence of an intense developing typhoon near Japan so late as November is probably even rarer than a similar development in the West Indies. It is known that there is a connexion between the variations of the general circulation of the atmosphere and the regions of formation as well as the direction and speed of travel of tropical cyclones, but it is very doubtful whether the cause of the present abnormal prolongation of the cyclone season can be explained. It is points like this which may be cleared up when meteorologists possess a long series of daily synoptic charts for the northern hemisphere such as those now being prepared by the Deutsche Seewarte, Hamburg, described in Nature of November 12, p. 748 .

\section{An Easily Portable Episcope}

THE increasing appreciation of the value of episcopes in teaching has created a demand for an instrument, simple in construction, easy to handle, capable of being brought readily into the ordinary class room, and reasonably cheap. The Wigmore episcope which has been recently put on the market by Messrs. Newton and Co., 72, Wigmore Street, London, W.1, seems likely to meet this demand. It is light and, being provided with two carrying handles, can be easily carried from one room to another. It can be immediately installed and used in any room which has a projection screen and an electric lighting supply. In use, the episcope is simply placed upon the object to be shown on the sereen; the externally mounted reversing mirror is tilted to bring the image to the required height; and the image is then brought into focus. Two 250 -watt lamps are used for illuminating the field, which is 5 in. by 5 in.; but the map or drawing or book, a portion of which is to be projected, may be of any size. When the instrument is about $10 \mathrm{ft}$. from the screen, a well-illuminated picture $4 \mathrm{ft}$. square is 